\title{
Present role of dynamic tests of thyroid function
}

\author{
R. HALL, Y. SACHDEV, AND D. C. EVERED \\ From Endocrine Unit Department of Medicine, Royal Victoria Infirmary, Newcastle upon Tyne
}

Dynamic tests are of value in the diagnosis of minor degrees of thyroid dysfunction where basal hormone estimations are often within the so-called conventional normal range. Dynamic tests can be divided into two categories: stimulation tests where stimuli are applied in an attempt to increase hormonal secretion or hormonal action and suppression tests where the reverse applies. Dynamic tests can be applied at the level of the hypothalamus, pituitary, thyroid, or tissues and this classification will be used in the description of the tests available.

\section{Hypothalamic Tests}

\section{STIMULATION TESTS}

Stimuli acting at hypothalamic levels or above form the basis of many endocrine tests. Hall, Amos, and Ormston (1971) described elevation of serum TSH levels one week after the administration of carbimazole and iodides whereas the former alone had proved ineffective. A variety of indirect methods for measuring TSH reserve are available such as those of Studer (1962) and of Mornex and Berthezene (1970). The latter method involves measuring the plasma inorganic iodide (PII) by isotope dilution before and 36 hours after a small dose of carbimazole (15 mg/day) for a week. The PII increases in normal subjects but not in those with hypopituitarism. However all of these tests are too cumbersome for routine use and there is at present no satisfactory method of inducing TSH release via the hypothalamus.

\section{SUPPRESSION TESTS}

Pharmacological doses of corticosteroids are capable of reducing TSH secretion in normal subjects and patients with primary thyroid failure (Wilber and Utiger, 1969). Since thyroid overactivity is only very rarely induced by TSH secretion these tests are of little routine value.

\section{Pituitary Tests}

STIMULATION TESTS

The availability of synthetic thyrotrophin-releasing hormone (TRH), a tripeptide, has allowed detailed measurements of pituitary TSH reserve. Now that 8 TSH radioimmunoassays are available the short in- ${ }_{\infty}$ travenous test is most suitable. Here serum TSH $\omega$ levels are measured before and 20 and 60 minutes after the rapid intravenous injection of $200 \mu \mathrm{g}$ of $\stackrel{+}{\infty}$ TRH in $2 \mathrm{ml}$ of saline. The normal range of response $\mathrm{S}$ (table I) has been described by Ormston et al $\vec{T}$ (1971), but each laboratory should determine its own range of normality.

\begin{tabular}{llll}
\hline & Men & Women & Significance \\
\hline Basal & $1 \cdot 6$ & $1 \cdot 4$ & \\
& $(<0.5-2 \cdot 8)$ & $(<0.5-2 \cdot 7)$ & NS \\
Twenty min & $9 \cdot 5$ & $13 \cdot 5$ & \\
after TRH & $(3 \cdot 5-15 \cdot 6)$ & $(6 \cdot 5-20.5)$ & $\mathrm{P}<0.001$ \\
Sixty min & $6 \cdot 8$ & $9 \cdot 8$ & \\
after TRH & $(2 \cdot 0-11 \cdot 5)$ & $(4 \cdot 0-15 \cdot 6)$ & $\mathrm{P}<0.001$ \\
\hline
\end{tabular}

Table I Normal range of response of serum TSH $(\mu \mathrm{U} / \mathrm{ml}, \mathrm{MRC}$ Standard 68/38 HTSH) to TRH, $200 \mu \mathrm{g}$ IV

Women show a greater response than men at both 20 and 60 minutes due to the effect of their:higher oestrogen levels. The TSH response to TRH is not obviously affected by age, height, weight, oro̊ surface area. The response can be enhanced by oestrogens, by theophylline, or by antithyroido drug therapy. It is diminished by thyroid hormones, $D$ by pharmacological doses of corticosteroids, and by․ㅡㄹ long-term (but not short term) L-dopa. By measuringñ serum $T_{3}$ levels, which peak about three hours after intravenous TRH, the whole pituitary-thyroid axis $\tilde{O}$ can be tested. After oral TRH in a dose of $40 \mathrm{mg}$ the TSH response is greater and produces measurableo changes in both serum $T_{3}$ and $T_{4}$ levels, the formero peaking at about three hours, the latter reaching $\mathrm{a}_{\mathbb{\infty}}$ plateau after four to six hours. Serum $T_{3}$ measure- $\stackrel{\oplus}{+}$ ments are preferable to those of $T_{4}$ because the 0 $T_{3}$ assay allows more precise measurement of the small changes in thyroid hormone levels which occur.

The TRH test is of value in the following clinical的 situations (Hall, Ormston, Besser, Cryer, and McKendrick, 1972): 


\section{To test pituitary TSH reserve}

A normal TSH response to TRH excludes pituitary TSH deficiency whereas an absent or impaired response indicates subjects at risk for hypothyroidism and is not in itself an indication for treatment. In acromegaly absent or impaired responses are frequent in euthyroid subjects.

\section{To indicate hypothalamic disease}

A normal peak response can be seen in patients who are hypothyroid because of hypothalamic disease. Patients with hypothalamic disease more often have a delayed response to TRH.

To exclude hyperthyroidism

Patients with even minor degrees of hyperthyroidism show failure of TSH response to TRH and thus a normal response excludes hyperthyroidism.

\section{To confirm the presence of thyroid dysfunction}

An absent TSH response to TRH is seen in a number of situations where there is no clinical evidence of hyperthyroidism. These include ophthalmic Graves' disease and uni- or multinodular goitre. Failure of TSH response to TRH correlates well with absence of $T_{3}$ suppression of thyroidal radioiodine uptake and a normal TRH test correlates well with normal suppressibility. The TRH test should now replace the $T_{3}$ suppression test as an indicator of autonomous thyroid function.

\section{To confirm minor thyroid failure}

Elevated basal TSH levels are usually sufficient confirmatory evidence of major thyroid failure. However when basal TSH levels are only minimally elevated, the exaggerated and prolonged TSH response to TRH provides confirmation of some degree of thyroid failure.

\section{SUPPRESSION TESTS}

The $T_{3}$ suppression test is routinely used to demon- strate whether thyroid function is under pituitary TSH control. $T_{3}$ suppresses TSH output at the pituitary level and hence in normal circumstances causes a fall in the thyroidal radioiodine uptake. As mentioned earlier the TRH test has now replaced the $T_{3}$ suppression test.

A variety of criteria are used to define normal, partial, and absent suppression but since thyroid suppressibility is almost certainly a continuum, these criteria should be regarded as empirical. Our criteria, based on six-hour thyroidal uptake of 131I before and eight days after the administration of $40 \mu \mathrm{g}$ of triiodothyronine thrice daily, are: normal suppression-second six-hour ${ }^{131}$ I uptake $<11 \%$ dose; partial suppression-second six-hour 131I uptake $>11 \%$ but $<20 \%$ dose and fall in uptake $5 \%$ or more compared with first test; absent suppression-second six-hour ${ }^{131}$ I uptake $>20 \%$ or fall in uptake $<5 \%$ from an initial uptake $>11 \%$.

\section{Thyroid Tests}

\section{STIMULATION TESTS}

Administration of exogenous TSH, usually of bovine origin, can be used to demonstrate the presence of normal thyroid reserve by measuring the change in thyroidal radioiodine uptake or circulating thyroid hormone level produced. Early measurements with ${ }^{132} \mathrm{I}, 99 \mathrm{~m} \mathrm{Tc}$, or later measurements with ${ }^{131}$ I can be used. A standard thyroid ${ }^{131}$ I uptake at 24 hours, ${ }^{132}$ I uptake at four hours, or $99 \mathrm{mTc}$ at 20 minutes is determined. Three injections each of $10 \mathrm{iu}$ of Thyrotropan (Armour TSH) are given intramuscularly on consecutive days. On the third day a further trace dose is given, and a second uptake determined. If ${ }^{131}$ I has been used, more than one week must be allowed to elapse between tests or the residual week uptake must be counted before the second tracer dose.

A normal response is indicated by doubling of the control value or an increase in uptake of more than

\begin{tabular}{lllll}
\hline $\begin{array}{l}\text { Grade of } \\
\text { Hypothyroidism }\end{array}$ & $\begin{array}{l}\text { Mean } P B I \\
\text { as nmol } T_{4} / l \\
(m g / 100 ~ m l)\end{array}$ & $\begin{array}{l}\text { Thyroid Hormone } \\
\text { Binding Test } \\
(\text { Thyopac-3) }\end{array}$ & $\begin{array}{l}\text { Mean Serum TSH } \\
(\mu U / m l)\end{array}$ & $\begin{array}{c}\text { TSH Stimulation Test } \\
(\% \text { abnormal })\end{array}$ \\
\hline Overt & $\begin{array}{c}62 \\
(3.1)\end{array}$ & 1.23 & 91 & $100 '$ \\
Mild & $\begin{array}{c}92 \\
(4.6)\end{array}$ & 1.15 & 17.9 & 50 \\
Subclinical & $\begin{array}{l}108 \\
(5.4)\end{array}$ & 1.09 & 11.2 & 23 \\
$\begin{array}{l}\text { Autoimmune thyroid } \\
\text { disease }\end{array}$ & 5.6 & 1.08 & 1.7 & 0 \\
\hline
\end{tabular}

Table II TSH stimulation test in hypothyroidism 
15 per cent whichever is greater. Using serum $T_{4}$ as the index of response Williams, Ekins, and Ellis (1969) found that the smallest rise of serum $T_{4}$ in normal individuals 24 hours after intramuscular injection of $10 \mathrm{iu}$ of TSH was $39 \%$. However, results of the TSH stimulation test must be interpreted with caution. Although lack of thyroid reserve is almost invariably found in patients with myxoedema, we have found the test to be normal in half of a series of patients with mild hypothyroidism and a normal response was found in $77 \%$ of patients with subclinical hypothyroidism (table II). It is therefore apparent that the large dose of TSH employed in the test is capable of stimulating radioiodine uptake in some subjects with mild hypothyroidism. The TSH stimulation test has now largely been replaced by measurement of the serum TSH level in the diagnosis of primary hypothyroidism.

\section{SUPPRESSION TESTS}

Iodides can be used to cause suppression of the 24-hour thyroidal radioiodine uptake. After $2 \mathrm{mg}$ of iodide there is only minimal suppression of uptake in normal subjects (mean percentile fall $35 \%$ ) whereas patients with hyperthyroidism, Hashimoto's thyroiditis (mean percentile fall $84 \%$ ), and iodide goitre show marked suppression (Paris, McConahey, Tauxe, Woolner, and Bahn, 1961).

\section{Tissue Tests}

STIMULATION TESTS

A variety of abnormalities in cellular function can be used as indices of hypothyroidism but these are $\underline{\overrightarrow{0}}$ largely non-specific. Demonstration of an objective $\Rightarrow$ change in these measurements after the adminis- $\stackrel{5}{?}$ tration of $\mathbf{T}_{4}$ or $\mathbf{T}_{3}$ can be used as a more specific $\bar{\partial}$ test of thyroid failure, eg, a fall of $>70 \mathrm{mg} \%$ 을 in the serum cholesterol, or measurable improve- $\frac{\bar{s}}{7}$ ments in the tendon reflex duration or electro- $\stackrel{\mathbb{D}}{\square}$ cardiogram.

\section{SUPPRESSION TESTS}

Perhaps the best known is the therapeutic trial of $\overrightarrow{\vec{\omega}}$ antithyroid drugs in a patient with suspected $\stackrel{\omega}{\omega}$ hyperthyroidism but this is difficult to monitor 용 by other than subjective means.

\section{References}

Evered, D. C., Ormston, B. J., Smith, P. A. Hall, R and Bird, T (1973). Grades of hypothyroidism. Brit. med. J., 1, 657-662.

Hall, R., Amos, J., and Ormston, B. J. (1971). Radioimmunoassay of $\rightarrow$ human serum thyrotrophin. Brit. med. J., 1, 582-586.

Hall, R., Ormston, B. J., Besser, G. M., Cryer, R. J., and McKendrick, d M. (1972). The thyrotrophin-releasing hormone test in diseases $\overline{\widehat{O}}$ of the pituitary and hypothalamus. Lancet, 1, 759-763.

Mornex, R., and Berthezene, F. (1970). Comments on a proposed new way of measuring thyrotrophin (TSH) reserve. J. clin. Endocr., 31, 587-589.

Ormston, B. J., Garry, R., Cryer, R. J., Besser, G. M., and Hall, R. (1971). Thyrotrophin-releasing hormone as a thyroid function test. Lancet, 2, 10-14.

Paris, J., McConahey, W. M., Tauxe, W. N., Woolner, L. B., and Bahn, R. C. (1961). The effects of iodides on Hashimoto's $\bar{O}$ thyroiditis. J. clin. Endocr., 21, 1037-1043.

Studer, H. (1962). Der TSH-Reservetest mit Carbimazol. Helv. med. 으 Acta, 29, 275-310.

Wilber, R. F., and Utiger, R. D. (1969). The effect of glucocorticoids on thyrotrophin secretion. J. clin. Invest., 48, 2096.

Williams, E. S., Ekins, R. P., and Ellis, S. M. (1969). Thyroid stim- 3 ulation test with serum thyroxine concentration as index of response. Brit. med. J., 4, 336-338. 